\title{
Gagnsemi hugrænnar atferlismeðferðar við lyndis- og kvíðaröskunum hjá fullorðnum
}

\author{
Magnús Blöndahl Sighvatsson¹ sálfræðingur, Hafrún Kristjánsdóttir'1,2 sálfræðingur, Engilbert Sigurðsson¹,2 læknir, \\ Jón Friðrik Sigurðsson ${ }^{1,2}$ sálfræðingur
}

\section{ÁGRIP}

Hugræn atferlismeðferð (HAM) er sú sálfræðimeðferð sem mestar rannsóknarheimildir liggja að baki í meðferð lyndis- og kvíðaraskana hjá fullorðnum. í pessari yfirlitsgrein verður HAM kynnt, fjallað verður um niðurstöður árangursrannsókna, langtímaárangur og gagnsemi sampættrar meðferðar með lyfjum og HAM. Jafnframt verður fjallað stuttlega um kosti og galla hópmeðferðar samanborið við einstaklingsmeðferð og hvaða áhrif samsláttur fleiri en einnar röskunar hefur á árangur HAM. Í greininni kemur fram að HAM gagnast vel við punglyndi, almennri kvíðaröskun, skelfingarkvíða, áfallastreituröskun, áráttu- og práhyggju, félagsfælni og sértækri fælni. Árangur af HAM við meðferð pessara raskana er í flestum tilfellum sambærilegur eða betri en árangur lyfjameðferðar en aðgengi er lakara. Langtímaárangur virðist góður en rannsóknir á sampættum áhrifum HAM og lyfja eru skammt á veg komnar og pví erfitt að álykta um gagnsemi sampættrar meðferðar.

${ }^{1}$ Landspítala ææknadeild Hí.

Fyrirspurnir: Hafrún Kristjánsdóttir,

hafrunkr@landspitali.is

Höfundar vilja pakka Paul M. Salkovskis fyrir ráđgjöf við val á heimildum.

Barst: 27. janúar 2011 - sampykkt til birtingar:

11. október 2011

Höfundar tiltaka engin hagsmunatengsl.

\section{Inngangur}

Hugræn atferlismeðferð (HAM, cognitive behavioral therapy) er sálfræðimeðferð sem hefur náð mikilli útbreiðslu á tiltölulega skömmum tíma. ${ }^{1}$ Pví er mikilvægt fyrir lækna og annað heilbrigðisstarfsfólk að kynnast hugmyndafræði meðferðarinnar, pekkja hvernig hún fer fram og ekki síður hvar hún skilar mestum árangri og hver langtímaárangur er í samanburði við lyfjameðferð og aðra sálfræðilega meðferð. HAM byggir á rökhyggju og skipulagi og er afmörkuð í tíma, par sem flestir meðferðarvísar við algengum geðröskunum, eins og punglyndi og kvíða, gera ráð fyrir 10-20 viðtölum. ${ }^{2}$ Ef vandinn er alvarlegur eða margpættur getur meðferðin varað lengur. Meðferðin stendur á góðum fræðilegum grunni í dag $^{3}$ og hún byggir á fleiri og vandaðri árangursrannsóknum en önnur form sálfræðimeðferðar við geðröskunum fullorðinna. ${ }^{1,3}$ Meðferðinni er nú mest beitt af sálfræðingum pótt geðlæknar, heimilislæknar, hjúkrunarfræðingar og fleiri heilbrigðisstéttir hafi sótt sér pjálfun í HAM í vaxandi mæli á síðustu misserum.

HAM er gjarnan kennd við bandaríska geðlækninn Aaron T. Beck sem var menntaður í sálgreiningu. Í rannsóknum sínum komst hann að pví að aðferðir sálgreiningar gengju ekki upp við meðferð punglyndis. ${ }^{1}$ 2,4 Beck var undir áhrifum frá hinni svokölluðu hugrænu byltingu í sálfræði sem átti sér stað á árunum 19501970 en pó ekki síður undir áhrifum frá aðferðum atferlismeðferðar. 2, 4 Á grunni rannsókna sinna og meðferðarreynslu byggði Beck pá kenningu að pað hvernig við hugsum, túlkum atburði og högum daglegu lífi ráði miklu um líðan okkar. ${ }^{4,5}$ Samkvæmt kenningu hans próa peir sem kljást við geðraskanir oft með sér bjagað mat á umhverfi og innri áreitum, svo sem líkamlegum einkennum. Мeð pví að kortleggja hugsun og hegðun peirra sem finna fyrir vanlíðan, megi skýra hvers vegna peir glíma við geðröskun og með pví að breyta hugsun og hegðun sé hægt að breyta líðan til hins betra. ${ }^{2,4,5}$

Nú hafa verið birtar yfir 300 árangursrannsóknir um beitingu HAM við meðferð geðraskana. Ekki verður annað sagt en meðferðin hafi reynst mjög gagnleg, ekki síst við við peim algengustu, svo sem punglyndi og kvíðaröskunum, ${ }^{3}$ og verður fjallað sérstaklega um gagnsemi HAM í meðferð pessara raskana í pessari grein.

Í HAM er skjólstæðingi kennt að bera kennsl á ósjálfráðar óhjálplegar hugsanir og meta hvaða áhrif atferli hefur á líðan. Skjólstæðingi er kennt að líta á hugsanir sínar sem tilgátu (eina af mörgum), en ekki endilega pá einu réttu. Pegar ósjálfráðar hugsanir tengdar vandanum og vanlíðan hafa verið kortlagðar er skjólstæðingi kennt að endurmeta hugsanir sínar með skipulögðum hætti og breyta hegðun með pað að markmiði að bæta líðan sína. ${ }^{5}$ Til útskýringar má taka dæmi af HAM við punglyndi. Hugsun pess punglynda einkennist iðulega af ofmati á mistökum í fortíð og vanmati á eigin getu til að ráða við daglegt líf. ${ }^{5}$ Pess vegna eru punglyndir oft ekki nægilega virkir, eiga erfitt með að framkvæma einföldustu hluti og draga sig í hlé. Í HAM lærir skjólstæðingur pví að kortleggja og endurmeta óhjálplegt mat sitt á fyrri mistökum, eigin getu og stöðu. Skjólstæðingi er einnig kennt að auka daglega virkni sína til að sporna við framtaksleysi. Petta er gert á skipulegan hátt par sem hinn punglyndi eykur virkni sína stig af stigi. ${ }^{5}$ Með öðrum orðum tileinkar hinn punglyndi sér nýjar aðferðir til að glíma við vanlíðan; lærir að greina og endurmeta ósjálfráðar niðurrifshugsanir; lærir að takast á við mótlæti og daglegt líf á annan hátt en áður og kannar hvort pað leiði ekki til breytinga á líðan. Pennan lærdóm tekur einstaklingurinn með sér inn í framtíðina. Pví heldur árangur HAM gjarnan áfram að skila sér eftir að meðferð 
lýkur, svo fremi sem skjólstæðingurinn beiti áfram peim aðferðum sem hann hefur lært í HAM. ${ }^{3-5}$ Í HAM við kvíða er líkri nálgun beitt. Unnið er með hugsanir á svipaðan hátt (pað er endurmat) en pað sem aðgreinir einna helst meðferð pessara tveggja flokka algengra raskana er að í kvíðameðferð er skjólstæðingur látinn mæta kvíðavekjandi áreitum. Til dæmis er einstaklingur með fælni gagnvart hundum settur í návígi við hund. Petta er gert í peim tilgangi að breyta háskalegu mati pess kvíðna („hundurinn bítur mig“) í raunhæfara mat („hundurinn getur bitið en gerir pað líklega ekki og parf ekki að vera hættulegur"). Slíkar aðferðir kallast atferlistilraunir/berskjöldun. ${ }^{6}$

Í pessu yfirliti eru kynntar árangursrannsóknir* á HAM-einstaklingsmeðferð við kvíða og punglyndi hjá fullorðnum á aldrinum 18-65 ára nema annað sé tekið fram, langtímaáhrif og hvort árangur meðferðar eykst eða minnkar með sampættri meðferð HAM og geðlyfja. Jafnframt er fjallað um hvaða áhrif pað hefur á meðferð ef skjólstæðingur glímir við fleiri en eina röskun, og loks um gagnsemi hópmeðferðar. Par sem samanburðurinn er flókinn ${ }^{7}$ hafa höfundar búið til töflu sem skýrir niðurstöður enn frekar, en í henni kemur fram yfirlit um árangursmat (fyrir og eftir meðferð, á langtímaáhrifum og áhrifum sampættrar meðferðar) ásamt áhrifastærðum par sem HAM er borin saman við biðlista eða lyfleysu.** Að lokum ræðum við stuttlega kosti og galla hópmeðferðar og samslátt geðraskana og hvaða áhrif slíkt hefur á árangur HAM.

\section{Lyndisraskanir}

\section{Dunglyndi}

Hugræn atferlismeðferð við punglyndi: Birtar hafa verið tæplega 100 árangursrannsóknir á HAM við punglyndi fullorðinna par sem slembivali er beitt. ${ }^{3}$ Pegar niðurstöður peirra eru skoðaðar í samantektarrannsóknum (meta-analysis) kemur í ljós að HAM sýnir marktækt betri árangur en engin meðferð, biðlisti og nokkurt annað form sálfræðimeðferðar, óháð alvarleika. ${ }^{3,8}$ Höfundum er kunnugt um nokkrar rannsóknir sem hafa borið saman árangur HAM og sálaraflsmeðferðar (psychodynamic therapy) í meðferð punglyndis. 7, 9, 10 Pær niðurstöður benda til að HAM gagnist betur. Árangur HAM og tveggja annarra sálfræðimeðferða; samskiptameðferðar (interpersonal therapy) og athafnameðferðar (behavioral activation) er hins vegar svipaður., ${ }^{3,8} 9$ I I athafnameðferð er lögð áhersla á að auka virkni, en hafa ber í huga að áhersla á aukna virkni er einnig einn af lykilpáttum HAM við punglyndi. ${ }^{5}$ Margar rannsóknir hafa einnig verið framkvæmdar par sem borinn er saman árangur HAM og punglyndislyfjameðferðar, pað er SSRI-lyfja (paroxetín), príhringalyfja (imipramín/nortriptylín/amitriptylín), MAO-hamlara (phenelzín) og annarra punglyndislyfja (nefazódón/búprópíon). Niðurstöður ber flestar að sama brunni, að pað sé ekki munur á árangri pessara meðferða við punglyndi, óháð alvarleika pess, við meðferðarlok..$^{3,10-12}$ Hafa ber pó í huga að í sumum tilfellum eru sjúklingar svo veikir að peir eiga í erfiðleikum með að nýta sér HAM á pví stigi veikindanna og pví hafa fremur fáar rannsóknir kannað gagn-

\footnotetext{
* Pegar rætt er um árangursmat er í öllum tilfellum verið að fjalla um minnkun einkenna, til dæmis færri kvíðaköst hjá peim sem pjást af skelfingarkvíða.

* Áhrifastærð er stöðluð mælieining á áhrifum meðferðar. Í pessari grein er samanburðurin við biðlista og/eða lyfleysu (placebo). Viðmið Cohen um magn áhrifa eru eftirfarandi 0,2 = lítil áhrif/ $0,5=$ miðlungs áhrif/ 0,8 = mikil áhrif.
}

semi HAM fyrir pennan sjúklingahóp. Pegar svo er, eru peir meðhöndlaðir með lyfjum eða raflækningum. Pví er ekki hægt að útiloka að lyfjameðferð skili meiri árangri en HAM við meðferð allra veikustu punglyndissjúklinga á legudeildum.

Langtímaárangur hugrænnar atferlismeðferðar við punglyndi: Gloageuen og félagar ${ }^{10}$ tóku saman gagnsemi HAM við vægu til alvarlegu punglyndi hjá fullorðnum og athuguðu meðal annars langtímaáhrif HAM. Í samantekt peirra var hlutfall hrösunar*** 12 mánuðum eftir að meðferð lauk hærra hjá einstaklingum sem fengu punglyndislyfjameðferð en peim sem fengu HAM (60\% í punglyndislyfjameðferð samanborið við 29\% í HAM). Eftirfarandi lyf voru notuð í samanburðinum: Príhringalyf (amitriptylín, klómipramín, nortriptylín, lófepramín og desipramín), norepineprín-hamlari (maprótilín), í einu tilfelli benzódíasepín (alprazólam) og punglyndislyf ekki nánar skilgreind. Pessar niðurstöður hafa verið endurteknar par sem SSRI-lyf (paroxetín) var haft til samanburðar., 13, 14 Í rannsókn Hollon og félaga var hrösun 12 mánuðum eftir meðferðarlok mun meiri í lyfjahópnum, samanborið við HAM-hópinn, auk pess sem hrösun í HAMhópnum var sambærileg við hrösun hjá peim hópi sjúklinga sem enn var á lyfjum. Rannsóknir á langtímaáhrifum HAM við punglyndi gefa pví til kynna að HAM sé gagnleg jafnvel eftir að meðferð lýkur.

Sampætt HAM og lyfjameðferð við punglyndi: Niðurstöður rannsókna á sampættri meðferð við punglyndi eru misvísandi, en pær benda pó til pess að pað fari eftir pví hversu alvarlegt punglyndið er, hvort sampætt meðferð gefur betri árangur en HAM eða lyfjameðferð ein og sér. ${ }^{8,15,16}$ Rannsóknir á vægu og meðaldjúpu punglyndi benda til pess að HAM gagnist best og að lyfjameðferð (nortriptylín) bæti ekki neinu við árangur ${ }^{15,17}$ en pegar punglyndi er alvarlegt reynist best að beita pessum tveimur meðferðum (HAM og nefazódón) samtímis. ${ }^{15}, 18$ Rannsóknir hafa einnig sýnt að sampætt meðferð par sem HAM er beitt eftir að lyfjameðferð lýkur er árangursrík, meðal annars með tilliti til bakslags. ${ }^{19}$

\section{Óyndi}

Hugræn atferlismeðferð við óyndi: Í nýlegri yfirlitsgrein ${ }^{11}$ um árangur sálfræði- og lyfjameðferðar við punglyndi kom fram að árangur lyfjameðferðar við óyndi, í öllum tilfellum með SSRI-lyfjum (paroxetín, flúoxetín, sertralín), var betri en árangur sálfræðimeðferða. Í samanburðinum voru HAM, samskiptameðferð og lausnamiðuð meðferð. Hafa ber pó í huga að í flestum yfirlitsgreinum um meðferð óyndis er árangur mismunandi sálfræðimeðferða borinn saman við árangur mismunandi lyfjameðferða. Höfundum er aðeins kunnugt um eina samanburðarrannsókn par sem HAM var borin sérstaklega saman við SSRI-lyfjameðferð (flúoxetín). ${ }^{20}$ Í peirri rannsókn kom enginn munur fram.

Langtímaárangur hugrænnar atferlismeðferðar við óyndi: Höfundum er aðeins kunnugt um eina rannsókn með afar fáum pátttakendum og engum samanburðarhópi. Langtímaárangur HAM var góður hjá peim sem pátt tóku, sex mánuðum eftir meðferðarlok. ${ }^{21}$ Rannsóknum á langtímaárangri HAM við óyndi er pví verulega ábótavant.

Sampætt HAM og lyfjameðferð við óyndi: Í nýrri yfirlitsgrein ${ }^{22}$

*** Hrösun: Að veikjast aftur eftir að hafa náo bata í meðferð. 
Tafla I. Yfirlit um árangursrannsóknir og áhrifastærðir.

\begin{tabular}{|c|c|c|c|c|c|}
\hline Röskun & Meðferð & Árangur fyrir og eftir meðferð & Áhrifastærð* & Langtímaáhrif & Sameiginleg meðferð \\
\hline \multirow[t]{4}{*}{ Punglyndi ${ }^{3,7-19}$} & HAM & + & $0,82-0,89$ & + & Fer eftir alvarleika \\
\hline & AM & + & & & \\
\hline & Samskiptameðferð & + & & & \\
\hline & Lyfjameðferð & + & & - & \\
\hline \multirow[t]{2}{*}{ Óyndi11, 20-23 } & HAM & $?$ & $1,22^{* \star}$ & $?$ & $?$ \\
\hline & Lyfjameðferð & + & & & \\
\hline \multirow[t]{2}{*}{ Almenn kvíðaröskun 3, 24-27, 48} & HAM & + & $0,29-3,29$ & + & $+/ ?$ \\
\hline & Lyfjameðferð & + & & $?$ & \\
\hline \multirow[t]{3}{*}{ Skelfingarkvíðji, 14, 28-35, 48} & HAM & ++ & $0,57-1,44$ & ++ & - \\
\hline & Aðrar meðferðir & - & & - & \\
\hline & Lyfjameðferð & $-/ ?$ & & $?$ & \\
\hline \multirow[t]{3}{*}{ Áfallastreituröskun $3,14,36-43$} & HAM & + & $1,34-1,70$ & + & $?$ \\
\hline & EMDR & + & & & \\
\hline & Lyfjameðferð & $+/-$ & & $?$ & \\
\hline \multirow[t]{4}{*}{ Árátta og práhyggja ${ }^{3,45-50}$} & HAM & + & $1,30-1,86^{\star \star}$ & + & $=$ \\
\hline & BMS & + & & + & \\
\hline & Aðrar meðferðir & - & & & \\
\hline & Lyfjameðferð & + & & - & \\
\hline \multirow[t]{3}{*}{ Félagsfælni'14, 48, 51-54 } & HAM & + & $0,29-2,30$ & + & $=/ ?$ \\
\hline & Aðrar meðferðir & - & & & \\
\hline & Lyfjameðferð & + & & - & \\
\hline \multirow[t]{2}{*}{ Sértæk fælni $i^{14,55-57}$} & HAM & ++ & $0,48-1,05$ & ++ & $-/ ?$ \\
\hline & Lyfjameðferð & - & & - & \\
\hline
\end{tabular}

HAM Hugræn atferlismeðferð. AM Athafnameðferð. BMS Berskjöldun með svörunarhömlun.

? Frekari rannsókna er pörf.

+ Rannsóknarheimildir fyrir árangri.

++ Kjörmeðferð.

- Árangur ekki til staðar fyrir og eftir meðferð eða HAM árangursríkari, árangur viðhelst ekki i langtímarannsóknum, eða sameiginleg meðferð gagnast ekki betur en HAM eða

lyfjameðferð ein og sér.

= Sameiginleg meðferð og HAM jafnáhrifaríkar.

*Áhrifastærð er stöðluð mælieining á áhrifum meðferðar. Í pessari töflu er samanburðurinn við biðlista og/eða lyfleysu (placebo). Viðmið Cohen‘s um magn áhrifa eru eftirfarandi: 0,2 = lítil áhrif/ 0,5 = miðlungs áhrif/ 0,8= mikil áhrif.

**Áhrifastærð metin fyrir og eftir meðferð eingöngu, en ekki með samanburði við biðlista eða lyfleysu par sem gögn vantar.

kom fram að bæði sameiginleg meðferð (lyfjameðferð og sálfræðimeðferð) og lyfjameðferð ein og sér væri betri en sálfræðimeðferð ein og sér. Líkt og áður hefur komið fram, var árangur mismunandi samtalsmeðferða (HAM, samskiptameðferð, lausnamiðuð meðferð, félagsfærni, stuðningsmeðferð) í pessari yfirlitsgrein borinn saman við árangur mismunandi lyfjameðferða, pað er SSRI-lyfja (sertralín, paroxetín, flúoxetín) og MAO-hamlara (moklóbemíð). Höfundar pekkja til einnar rannsóknar á gagnsemi sampættrar meðferðar við óyndi en í henni var sampætt meðferð með SSRI-lyfi (sertralín) og HAM í hóp borin saman við lyfjameðferð. ${ }^{23}$ Par kom fram að sampætt meðferð gagnaðist betur en lyfjameðferð ein og sér, en hafa ber í huga að ólíkt öðrum rannsóknum sem fjallað er um í pessari grein var um hópmeðferð að ræða.

\section{Kví̉araskanir}

\section{Almenn kvíðaröskun}

Hugræn atferlismeðferð við almennri kvíðaröskun: Samkvæmt niðurstöðum samantektarrannsókna eru áhrif HAM við almennri kvíðaröskun meiri en áhrif lyfleysu, biðlista, ósérhæfðrar samtalsmeðferðar, sálaraflsmeðferðar, stuðningsviðtala og slökunar. ${ }^{3,}$ 24-26 Árangur af HAM, kerfisbundinni slökun (applied relaxation) og lyfjameðferð í meðferðarlok er sambærilegur. ${ }^{3,25,26}$ Hafa ber í huga að í peim sex rannsóknum sem framkvæmdar hafa verið á HAM og lyfjum var í öllum tilfellum nema einu um að ræða róandi lyf (benzódíazepín). ${ }^{3,} 26$

Langtimaárangur hugrænnar atferlismeðferðar við almennri kvíðaröskun: Rannsóknir á langtímaáhrifum HAM við almennri kvíðaröskun benda til að árangur haldist allt að 12 mánuðum eftir að meðferð lýkur og aukist eftir pví sem lengra líður frá meðferð.", ${ }^{25}$ Frekari árangursrannsókna er pörf, pví ekki er vitað hvort langtímaáhrif HAM eru meiri eða minni en áhrif lyfjameðferðar einnar og sér, par sem birtar árangursrannsóknir eru enn afar fáar.

Sampætt meðferð við almennri kvíðaröskun: Hugræn atferlismeðferð og lyfjameðferð: Höfundum er aðeins kunnugt um eina rannsókn ${ }^{27}$ sem bar saman HAM, lyfjameðferð með róandi lyfjum (díazepam), sampætta meðferð, HAM og lyfleysu, og lyfleysu eina og sér. Par kom fram að hlutfall hrösunar var mun hærra hjá peim hópi sem páði lyfjameðferð eða sampætta meðferð en peim sem einungis fengu HAM. Frekari árangursrannsóknir skortir pví á sampættri meðferð við almennri kvíðaröskun.

\section{Skelfingarkvíði}

Skelfingarkvíði með eða án víðáttufælni. Rannsóknir sýna að að öllu jöfnu reynist HAM betur við skelfingarkvíða en önnur meðferðarform, par með talin lyfjameðferð. ${ }^{3}$ Pau lyf sem athuguð hafa verið eru: príhringalyf (imipramín, klómípramín), SSRI-lyf 
(zimelídín), MAO-hamlara (phenelzín), róandi lyf (alprazólam, díazepam), beta-blokkar (própanolól), trazódón, klónidín. ${ }^{28}$ HAM ætti pví að vera fyrsta val í meðferð skelfingarkvíða. ${ }^{29}$ Í pessu samhengi skal tekið sérstaklega fram að sterkar vísbendingar eru um að langtímanotkun benzodíazepín-lyfja í meðferð á skelfingarkvíða geti verið skaðleg. ${ }^{29-31}$ Pegar skoðað er nánar hvaða pættir HAM skila árangri, benda rannsóknir til pess að atferlistilraunir/berskjöldun með slökunaræfingum eða öndunaræfingum beri mestan árangur, raunar töluvert meiri árangur en vinna með hugsanir eingöngu. ${ }^{32}$ Engar vísbendingar eru um að dáleiðsla, samskiptameðferð, neurolinguistic programming (NLP), lausnamiðuð meðferð, sálaraflsmeðferð og streitustjórnun beri árangur við meðferð á skelfingarkvíða. ${ }^{29}$

Langtímaárangur hugrænnar atferlismeðferðar við skelfingarkviða mеð еða án víđáttufxlni: Allmargar rannsóknir hafa farið fram á langtímaáhrifum HAM og par hafa samanburðarhóparnir verið lyfjameðferð, slökun eða biðlistahópur. ${ }^{14,28}$ Gould og félagar ${ }^{28}$ tóku saman langtímaáhrif HAM og lyfjameðferðar við skelfingarkvíða með eða án víðáttufælni úr 12 rannsóknum. Í peim rannsóknum voru lyfjaflokkarnir einungis príhringalyf (imipramín) eða róandi lyf (alprazólam). Par kom fram að peim sem fengu lyfjameðferð fór aftur en árangur HAM hélst minnsta kosti sex mánuðum eftir að meðferð lauk. Vert er að nefna tvær rannsóknir á langtímaáhrifum meðferðar við skelfingarkvíða. ${ }^{33,34}$ Sú fyrri er rannsókn Barlow og félaga $^{33}$, en par var hlutfall hrösunar í sex mánaða eftirfylgd $18 \%$ í HAM, 17\% í HAM og lyfleysu, en 40\% í punglyndislyfjameðferð (imipramín) og 48\% í sampættri meðferð. Í seinni rannsókninni sem framkvæmd var af van Apeldoorn og félögum ${ }^{34}$ var HAM borin saman við sampætta meðferð og SSRI-lyfjameðferð (par sem læknir gat valið á milli eftirfarandi lyfja: paroxetín, sertralín, flúvoxemín, citalópram og flúoxetín). Í peirri rannsókn kom ekki fram neinn munur á milli hópa í 12 mánaða eftirfylgd. Hafa verður í huga pegar niðurstöður pessara tveggja rannsókna eru metnar, að pátttakendur í rannsókn Barlow og félaga voru mun fleiri og fjölpættari samanburður á milli meðferða gerður. Pegar niðurstöður rannsókna á langtímaáhrifum HAM eru teknar saman benda pær til að HAM við skelfingarkvíða með eða án víðáttufælni nýtist notendum eftir að meðferð lýkur en ennpá er óljóst hvort punglyndislyfjameðferð dragi úr langtímaárangri HAM.

Sampætt meðferð við skelfingarkvíða: Rannsóknir gefa til kynna að sampætt meðferð komi betur út við meðferðarlok en HAM eða punglyndislyfjameðferð, ${ }^{35}$ en pegar dregið er úr lyfjameðferð virðist árangur sampættrar meðferðar minnka. Lyf virðast í sumum tilfellum trufla virkni HAM, samanber tíðnitölur hrösunar í kaflanum hér á undan. Hafa ber pó í huga nýja rannsókn van Apeldoorn og félaga ${ }^{34}$ par sem enginn munur kom í ljós á milli HAM og sampættrar meðferðar.

\section{Áfallastreituröskun}

Hugræn atferlismeðferð við áfallastreituröskun: Раð kemur ef til vill ekki á óvart að peir sem fá HAM við áfallastreituröskun ná marktækt meiri bata en hinir sem eru á biðlista fyrir meðferð.,36 Auk pess hefur HAM einnig áhrif á punglyndis- og almenn kvíðaeinkenni hjá peim sem pjást af áfallastreituröskun. ${ }^{37}$ Nokkrar útfærslur eru til af HAM við áfallastreitu og árangur pessara aðferða er sambærilegur. ${ }^{36-38}$ Önnur meðferðarform sem rannsóknir hafa sýnt fram á að beri árangur við meðferð á áfallastreitu eru eye-movement desensitization and reprocessing (EMDR) og punglyndislyfjameðferð. Ekki hefur tekist að sýna fram á mun á HAM og EMDR. ${ }^{36,37}$ Höfundum er einungis kunnugt um eina rannsókn með fáum pátttakendum par sem borin var saman árangur HAM og SSRI-lyfjameðferðar (paroxetín) ${ }^{39}$ og sýndi HAM betri árangur. Pegar áhrifastærðir úr margvíslegum slembivalsrannsóknum á punglyndislyfjameðferð annars vegar og HAM hins vegar eru bornar saman, kemur í ljós að áhrifastærðir eru mun stærri fyrir HAM. ${ }^{40,41}$ Í rannsókn Penava og félaga ${ }^{41}$ voru eftirfarandi lyfjaflokkar athugaðir: SSRI-lyf (flúoxetín), príhringalyf (imipramín, desipramín, og amitriptylín), MAOhamlarar (phenelzín) og róandi lyf (alprazólam). Pví er veruleg pörf á frekari rannsóknum sem bera saman HAM og lyfjameðferð.

Langtímaárangur hugrænnar atferlismeðferðar við áfallastreituröskun: Nokkur fjöldi rannsókna hefur athugað langtímaáhrif HAM við áfallastreituröskun og benda pær til að árangur haldist allt að 12 mánuðum eftir að meðferð lýkur. ${ }^{14,42}$

Sampætt meðferð við áfallastreituröskun: Hugræn atferlismeðferð og lyfjameðferð: Of fáar árangursrannsóknir hafa verið birtar sem fjalla um sampætta meðferð við áfallastreituröskun ${ }^{43}$ til að unnt sé að álykta um gagnsemi slíkrar meðferðar.

\section{Árátta og práhyggja}

Hugræn atferlismeðferð við áráttu og práhyggiu: Berskjöldun með svörunarhömlun (exposure-response prevention) og HAM eru pær meðferðir sem hafa reynst hvað best við meðhöndlun áráttu og práhyggju. Árangur peirra er svipaður. ${ }^{3}$ Pess ber að geta að í HAM við áráttu og práhyggju er berskjöldun með svörunarhömlun gjarnan notuð sem meginhluti af HAM og pá í formi atferlistilrauna, og pví kemur ekki á óvart að meðferðirnar séu álíka áhrifaríkar. ${ }^{44}$ Með pessari aðferð er sjúklingur berskjaldaður gagnvart áreiti sem honum finnst ópægilegt, án pess að hann fái tækifæri til að framkvæma áráttuhegðunina sem tengist pví. ${ }^{44}$ Engar haldbærar vísbendingar eru um að önnur meðferðarform, að punglyndislyfjameðferð undanskilinni (SSRIlyfin cítalópram, flúoxetín, flúvoxamín, paroxetín og sertralín og príhringalyfið klómipramín), gagnist í meðferð við áráttu og práhyggju. ${ }^{45}$ Sálgreining, dáleiðsla, smáskammtalækningar, jóga og sálaraflsmeðferð í hóp virðast ekki skila árangri. ${ }^{45}$

Langtímaárangur hugrænnar atferlismeðferðar við áráttu og práhyggju: Yfirgripsmikil rannsókn Foa og félaga ${ }^{46}$ bendir til að langtímaárangur af HAM sé góður. Hlutfall hrösunar í peirri rannsókn í priggja mánaða eftirfylgd var 11\% í HAM, en $45 \%$ á punglyndislyfjameðferð (klómipramín) og 13\% í HAM samhliða lyfjameðferð. Í samantekt Foa og Kozak á langtímaáhrifum HAM kom fram að 24\% sjúklinga hafði hrasað 29 mánuðum eftir meðferðarlok. ${ }^{47}$ Pví má álykta að HAM sé gagnleg eftir að henni lýkur, hvort sem henni er beitt samhliða lyfjameðferð eða ekki.

Sampætt meðferð við áráttu og práhyggju: Hugræn atferlismeðferð og lyfjameðferð: Rannsóknir benda til að árangur sampættrar meðferðar (klómipramín) sé góður en hann sé engu betri en árangur $\mathrm{HAM}^{48,49}$ og pví freistandi að álykta að lyfjameðferð bæti ef til vill litlu við HAM. Раð er pó tilhneiging fagaðila að nota sampætta meðferð fyrir sjúklinga með alvarlegustu einkennin og mestu fötlunina í daglegu lífi af peim sökum. ${ }^{50}$ Hins vegar benda rannsóknir á stærri hópum ekki til pess að sampætt meðferð sé betri en lyfjameðferð eða HAM ein og sér. ${ }^{48,50}$ 


\section{Félagsfalni}

Hugræn atferlismeðferð við félagsfælni: Rannsóknir hafa almennt sýnt fram á að HAM, ýmist í hóp- eða einstaklingsmeðferð, er árangursrík við félagsfælni. ${ }^{51}$ HAM er árangursríkari en engin meðferð og önnur sálfræðimeðferð. Rannsóknaniðurstöður eru misvísandi varðandi skammtímaárangur HAM samanborið við punglyndislyfjameðferð sem hefur verið SSRI-lyf (flúoxetín, flúvoxamín, sertralín), MAO-hamlarar (phenelzín, móklóbemíð) og önnur geðlyf (buspíron). ${ }^{51,52,53}$

Langtímaárangur hugrænnar atferlismeðferðar við félagsfxlni: Rannsóknir á langtímaáhrifum HAM við félagsfælni benda til að HAM sé árangursríkari en lyfjameðferð til lengri tíma. Í samanburðinum voru SSRI-lyf (sertralín, fluoxetín) og MAOhamlarar (phenelzín). ${ }^{14,51}$ Clark og félagar ${ }^{52}$ könnuðu áhrif einstaklingsmeðferðar og punglyndislyfjameðferðar (flúoxetín) við 12 mánaða eftirfylgd og par kom fram að HAM gagnaðist betur. Pví kann lyfjameðferð að vera jafngild HAM strax að lokinni meðferð, samanber umfjöllun í kaflanum á undan, en áhrifa HAM virðist gæta lengur. ${ }^{53}$

Sampætt meðferð við félagsfælni: Hugræn atferlismeðferð og lyfjameðferð: Рað var aðeins nýverið sem rannsóknir á sampættum áhrifum lyfja og HAM tóku að birtast. Flestar peirra rannsókna benda til pess að sampætt meðferð við félagsfælni gagnist ekki betur en HAM eða lyfjameðferð (SSRI-lyf: fluoxetín; MAOhamlarar: phenelzín; róandi lyf: alprazólam; önnur geðlyf: buspírón) og að HAM sé gagnlegri en lyfjameðferð til lengri tíma litið. $48,53,54$

\section{Sértæk fælni}

Sértæk fælni: Rannsóknir hafa sýnt að áhrifaríkasta meðferðin við sértækri fælni er HAM og lítill ágreiningur er um pað. ${ }^{55-57}$ Pví er ekki fjallað um önnur meðferðaform hér.

Langtímaárangur hugrænnar atferlismeðferðar við sértækri fælni: Rannsóknir á langtímaáhrifum HAM við sértækri fælni benda til að hrösun eftir meðferð sé fátíð, og allt að átta árum eftir að meðferð lýkur gæti áhrifa HAM enn. ${ }^{55-57}$ Pær fáu rannsóknir sem hafa verið framkvæmdar á áhrifum lyfjameðferðar, sérstaklega benzódíazepínlyfja (alprazólam), benda til aukinnar hættu á hrösun pegar meðferð lýkur og að slík meðferð kunni að trufla áhrif HAM í meðferð sértækrar fælni eða bæti litlu eða engu við. ${ }^{14,} 55,56$

Sampætt meðferð við sértækri fælni: Hugræn atferlismeðferð og lyfjameðferð: Par sem HAM eða atferlismeðferð eru undantekningarlaust pau meðferðarform sem gagnast best við sértækri fælni, pá er ekki mælt með lyfjameðferð í meðhöndlun hennar. ${ }^{55,}$ ${ }^{56}$ Fyrir vikið hafa nær engar rannsóknir farið fram á sampættum áhrifum lyfjameðferðar og HAM við sértækri fælni.

\section{Samsláttur geðraskana}

Mikilvægt er að hafa í huga að samsláttur (comorbidity) kvíðaraskana annars vegar og kvíða- og lyndisraskana hins vegar er mjög algengur. ${ }^{58}$ Í rannsókn Brown og félaga ${ }^{58}$ á klínísku pýði kom fram að 55\% pátttakenda voru með tvær eða fleiri kvíða- eða lyndisraskanir pegar rannsóknin fór fram. Pegar samsláttur kvíða- eða lyndisraskana einhvern tíma á æviskeiði pátttakenda (lifetime prevalence) var skoðaður, jókst hlutfallið í 76\%.
Mikilvægt er að hafa pennan samslátt í huga, pví að fjölmargar rannsóknir sýna að peir sem eru með kvíðatengt punglyndi svara verr lyfjameðferð en peir sem pjást einungis af kvíða eða af punglyndi. ${ }^{59}$ Petta vandamál virðist hins vegar ekki vera til staðar pegar HAM er beitt, pví samkvæmt árangursrannsóknum virðist samsláttur geðraskana ekki hafa áhrif á árangur HAM. ${ }^{60}$ Frekari árangursrannsókna er pó pörf.

\section{HAM í hóp- eða einstaklingsmeðferð}

Algengt er að boðið sé upp á hópmeðferð við peim röskunum sem fjallað hefur verið um hér að framan. Slíkt er skiljanlegt par sem mikilvægt er að horfa ekki aðeins til árangurs meðferðar heldur einnig hagkvæmni. Ljóst er að einstaklingsmeðferð er töluvert dýrara meðferðarform en hópmeðferð. Niðurstöður úr samantekt rannsókna par sem árangur HAM-einstaklingsmeðferðar við punglyndis- og kvíðaröskunum var borinn saman við árangur HAM-hópmeðferðar, benda til að munurinn sé lítill. ${ }^{61}$

Pegar talað er um HAM-hópmeðferð verður að hafa í huga að slík nálgun getur verið mismunandi, prátt fyrir að grunnatriðum HAM (til dæmis fræðslu, vinnu með hugsanir og atferli) sé í öllum tilfellum fylgt.

\section{Samantekt}

Eins og yfirlitið hér að ofan sýnir, er HAM árangursrík meðferð við lyndis- og kvíðaröskunum. Niðurstöður eftirfylgdarrannsókna sýna jafnframt að árangur HAM helst oft lengi eftir að meðferð lýkur. HAM er árangursríkari en önnur form sálfræðimeðferðar, að undanskilinni athafna- og samskiptameðferð við punglyndi par sem rannsóknir benda til jafn mikils árangurs. Sé HAM hins vegar borin saman við lyfjameðferð við punglyndi kemur í ljós að HAM er jafnáhrifarík eða áhrifaríkari, sérstaklega pegar horft er til langtímaáhrifa. Petta á pó ekki við um meðferð óyndis par sem SSRI-lyfjameðferð virðist skila meiri árangri en sálfræðimeðferð. Misvísandi niðurstöður hafa verið birtar um hvort lyfjameðferð bæti einhverju við HAM pegar sampætt meðferð er rannsökuð og pekkt eru dæmi um að lyfjameðferð geti jafnvel dregið úr árangri af HAM, svo sem í meðferð skelfingarkvíða.

Í flestum peim rannsóknum sem vísað hefur verið til í pessari grein var árangur HAM metinn í einstaklingsmeðferð. Rannsóknir seinni ára hafa pó sýnt fram á að hópmeðferð getur verið jafn árangursrík og einstaklingsmeðferð.

Klínískar leiðbeiningar National Institute for Health and Clinical Excellence - NICE (www.nice.org.uk) í Bretlandi eru til marks um hversu vel HAM hefur komið út í árangursrannsóknum. Í leiðbeiningum NICE er HAM að öllu jöfnu sú meðferð sem mælt er með að notuð sé fyrst við kvíðaröskunum ${ }^{24,29,37,45}$ og punglyndi. ${ }^{8}$ Pessar klínísku leiðbeiningar hafa verið pýddar og staðfærðar fyrir íslenskar aðstæður og eru á vef Landspítala og landlæknisembættisins. ${ }^{31}$

Pótt HAM standi á breiðari gagnreyndum grunni en önnur sálfræðimeðferð í dag, er frekari árangursrannsókna pörf. Í fyrsta lagi eru pær rannsóknir sem stuðst er við til að meta árangur HAM oftast gerðar við aðstæður par sem reyndir, vel pjálfaðir meðferðaraðilar sinna meðferðinni. Pví er vart hægt að ætlast til að árangur HAM geti orðið jafngóður og lýst er í pessari 
grein nema meðferðaraðilar mæti slíkum skilmerkjum. Í annan stað eru rannsóknir á sampættri meðferð komnar skammt á veg. Í priðja lagi eru árangursrannsóknir gjarnan gerðar á fremur einsleitum hópi sjúklinga sem endurspeglar ekki alltaf nægilega klínískan raunveruleika par sem vímugjafar, erfiðar félagslegar aðstæður og persónuleikaröskun getur flækt myndina. Að lokum er vert að nefna að í sumum samanburðarrannsóknum á HAM og lyfjameðferð hefur verið notast við príhringa punglyndislyf sem eru ekki lengur fyrsta lyfjameðferð við kvíða og punglyndi vegna aukaverkana og hættu á hjartsláttartruflunum, séu pau tekin í of stórum skömmtum.
Af yfirlitinu má álykta að HAM sé gagnleg meðferð við lyndisog kvíðaröskunum. Aukaverkanir eru nær aldrei vandamál og langtímaárangur að meðferð lokinni oft góður. Í pessari grein leyfir rýmið ekki að fjallað sé um árangur HAM við ýmsum öðrum vandamálum sem sálfræðingar, geðlæknar, heimilislæknar, lyflæknar og aðrir heilbrigðisstarfsmenn glíma við í starfi sínu. Dæmi um slíkt eru persónuleikaraskanir, geðklofi, geðhvarfasýki, fíknivandamál og átraskanir. Slík umfjöllun er efni í aðra grein.

ENGLISH SUMMARY

\section{Efficacy of cognitive behavioral therapy in the treatment of mood and anxiety disorders in adults}

Sighvatsson MB, Kristjánsdóttir H, Sigurðsson E, Sigurðsson JF

Cognitive behavioral therapy (CBT) represents that form of psychotherapy which has most research data to build on in the treatment of mood and anxiety disorders for adults. In this review we will introduce CBT and present the results of pertinent outcome research. Efficacy at the end of treatment is discussed, as well as long term effectiveness and the efficacy of combined treatment with medication and CBT. In addition, we discuss the pros and cons of group CBT compared to CBT in individual format, and comorbidity of mental disorders. According to this review CBT is efficacious for major depressive disorder, generalized anxiety disorder, panic disorder, post-traumatic stress disorder, obsessive compulsive disorder, social phobia and specific phobia. Efficacy of CBT is equal to or better than efficacy of drugs in the treatment of the above disorders, but there is less access to CBT. Longterm effectiveness of CBT appears to be good, but research on combined treatment is yet in its infancy and conclusions are premature on its place in treatment.

Key words: Cognitive behavioral therapy, psychotropic treatment, efficacy, long-term effects, combined treatment, mental disorders, adults.

Correspondence: Hafrún Kristiánsdóttir, hafrunkr@landspitali.is

\section{Heimildir}

1. Prochaska JM, Norcross JC. Systems of Psychotherapy: A Transtheoretical Analysis. 7th ed. Brooks/Cole, Pacific Grove California 2010.

2. Beck AT. How an anomalous finding led to a new system of psychotherapy. Nat Med 2006; 12: 1139-41.

3. Butler AC, Chapman JE, Forman EM, Beck AT. The empirical status of cognitive-behavioral therapy: a review of meta-analyses. Clin Psychol Rev 2006; 26: 17-31.

4. Beck AT. The current state of cognitive therapy: a 40-year retrospective. Arch Gen Psychiatry 2005; 62: 953-9.

5. Beck AT. Cognitive Therapy and the Emotional Disorders. Penguin Books, New York 1976

6. Bennett-Levy J, Butler $G$, Fennell $M$, Hackmann A Mueller, M, Westbrook D. Oxford Guide to Behavioral Experiments in Cognitive Therapy. Oxford University Press, Oxford 2004.

7. Tolin DF. Is cognitive-behavioral therapy more effective than other therapies? A meta-analytic review. Clin Psychol Rev 2010; 30: 710-20

8. National Institute for Clinical Exellence. Depression: the treatment and management of depression in adults (update). Clinical guideline 90. NICE, London 2009.

9. Cuijpers $P$, van Straten A, Andersson G, van Oppen P. Psychotherapy for depression in adults: a meta-analysis of comparative outcome studies. J Consult Clin Psychol 2008; 76: 909-22.

10. Gloaguen V, Cottraux J, Cucherat M, Blackburn IM. A meta-analysis of the effects of cognitive therapy in depressed patients. J Affect Disord 1998; 49: 59-72.

11. Cuijpers P, van Straten A, van Oppen P, Anderson G. Are psychological and pharmacological interventions equally effective in the treatment of adult depressive disorders? A meta analysis of comparative studies. J Clin Psychiatry 2008; 69: 1675-85.

12. DeRubeis RJ, Hollon SD, Amsterdam JD, et al. Cognitive therapy vs medications in the treatment of moderate to severe depression. Arch Gen Psychiatry 2005; 62: 409-16.

13. Hollon SD, DeRubeis RJ, Shelton RC, et al. Prevention of relapse following cogntive therapy vs medications in moderate to severe depression. Arch Gen Psychiatry 2005 62: 417-22
14. Hollon SD, Stewart MO, Strunk D. Enduring effects for cognitive behavior therapy in the treatment of depression and anxiety. Ann Rev Psychol 2006; 57: 285-315.

15. Otto MW, Smits JAJ, Reese HE. Combined psychotherapy and pharmacotherapy for mood and anxiety disorders in adults: review and analysis. Clin Psychol: Sci Pract 2005; 12: $72-86$.

16. Cuijpers P, van Straten A, Warmerdam L, Andersson G. Psychological treatment versus combined treatment of depression: A meta-analysis. Depress Anxiety 2009; 26 : 279-88

17. Murphy GE, Simons AD, Wetzel RD, Lustman PJ. Cognitive therapy and pharmacotherapy. Singly and together in the treatment of depression. Arch Gen Psychiatry 1984; 41: 33-41.

18. Keller MB, McCullough JP, Klein DN, et al. A comparison of nefazodone, the cogntive behavioral analysis system of psychotherapy, and their combination for the treatment of chronic depression. N Eng J Med 2000; 342: 1462-70.

19. Paykel ES. Cognitive therapy in relapse prevention in depression. Int J of Neuropsychopharmacol 2007; 10: 131-

20. Dunner DL, Schmaling KB, Hendrickson H, Becker J, Lehman A, Bea C. Cognitive therapy versus fluoxetine in the treatment of dysthymic disorder. Depression 1996; 4 34-41.

21. Stavinski A, Shahar A, Verreault R. A pilot study of the cognitive treatment of dysthymic disorder. Behav Psychother 1991; 19: 369-72.

22. Cuipers $P$, van Straten A, Schuurmans J, van Oppen $P$, Hollon SD, Andersson G. Psychotherapy for chronic major depression and dysthymia: a meta-analysis. Clin Psychol Rev 2010; 30: 51-62.

23. Ravindran AV, Anisman H, Merali Z, et al. Treatment of primary dysthymia with group cognitive therapy and pharmacotherapy: clinical symptoms and functional impairments. Am J Psychiatry 1999; 156, 1608-17.

24. National Institute for Clinical Exellence. Generalised anxiety disorder and panic disorder (with or without agoraphobia) in adults. Clinical guidelines 113. NICE, London 2011.
25. Robichaud M, Dugas MJ. Psychological treatments of generalized anxiety disorder. In: Antony MM, Stein MB, ed. Oxford Handbook of Anxiety and Related Disorders. Oxford University Press, New York 2009: 364-75.

26. Mitte, K. Meta-analysis of cognitive-behavioral treatments for generalized anxiety disorder: a comparison with pharmacotherapy. Psychol Bull 2005; 131: 785-95.

27. Power KG, Simpson RJ, Swanson V, Wallace LA. A controlled comparison of cognitive-behaviour therapy, diazepam, and placebo, alone and in combination, for the treatment of generalised anxiety disorder. J Anx Disord 1990; 4: 267-92.

28. Gould RA, Otto MW, Pollack MH. A meta analysis of treatment outcome for panic disorder. Clin Psychol Rev 1995; 15: 819-44.

29. National Institute for Clinical Exellence. Anxiety: Management of anxiety (panic disorder, with or without agoraphobia, and generalised anxiety disorder) in adults in primary, secondary and community care. Clinical guideline 22. NICE, London 2004

30. Wright J. Integrating cognitive behavioral therapy and pharmacotherapy. In: Leahy RL, ed. Contemporary Cognitive Therapy. Guilford, New York 2004: 341-67.

31. Agnarsdóttir A, Eypórsdóttir Á, Einarsson E, et al punglyndi og kvíði - klínískar leiðbeiningar. Landspítalinn 2011 www.landspitali.is - september 2011

32. Sánchez-Meca J, Rosa-Alcázar AI, Marín-Martínez F, Gómez-Conesa A. Psychological treatment of panic disorder with or without agoraphobia: A meta analysis. Clin Psychol Rev 2010; 30: 37-50.

33. Barlow DH, Gorman JM, Shear MK, Woods SW. Cognitivebehavioral therapy, imipramine, or their combination for panic disorder: A randomized controlled trial. JAMA 2000; 283: 2529-36.

34. van Apeldoorn, FJ, Timmerman ME, Merch PPA, et al. A randomized trial of cognitive-behavioral therapy or selective serotonin reuptake inhibitor or both combined for panic disorder with or without agoraphobia: treatment results through 1-year follow-up. J Clin Psychiatry 2010; 71: 574-86. 
35. Otto MW, Behar E, Smits JAJ, Hofmann SG. Combining pharmacological and cognitive behavioral therapy in the treatment of anxiety disorders. In: Antony MM, Stein MB, ed. Oxford Handbook of Anxiety and Related Disorders. Oxford University Press, New York 2009: 429-41.

36. Bisson J, Andrew M. Psychological treatment of posttraumatic stress disorder (PTSD). Cochrane Database Syst Rev 2007; 3: CD003388.

37. National Institute for Clinical Exellence. Post-traumatic stress disorder (PTSD): The management of PTSD in adults and children in primary and secondary care. Clinical guideline 26. NICE, London 2005.

38. Riggs DS, Foa EB. Psychological treatment of posttraumatic stress disorder and acute stress disorder. In: Antony MM Stein MB, ed. Oxford Handbook of Anxiety and Related Disorders. Oxford University Press, New York 2009: 41729.

39. Frommberger U, Stieglitz RD, Nyberg E, et al. Comparison between paroxetine and behaviour therapy in patients with posttraumatic stress disorder (PTSD): A pilot study. Int J Psychiatr Clin Pract 2004; 8: 19-23.

40. Powers MB, Halpern JM, Ferenschak MP, Gillihan SJ, Foa EB. A meta-analytic review of prolonged exposure for ptsd. Clin Psychol Rev 2010; 30: 635-41.

41. Penava SJ, Otto MW, Pollack MH, Rosenbaum JF. Current status of pharmacotherapy for PTSD: an effect size analysis of controlled studies. Depress Anxiety 1996; 4: 240-2.

42. Foa EB, Hembree EA, Cahill SP, et al. Randomized trial of prolonged exposure for posttraumatic stress disorder wit and without cognitive restructuring: outcome at academic and community clinics. J Consult Clin Psychol 2005; 73: 953-64.

43. Hetrick SE, Purcell R, Garner B, Parslow R. Combined pharmacotherapy and psychological therapies for post traumatic stress disorder (PTSD). Cochrane Database Syst Rev 2010; 7: CD007316.
44. Clark DA. Cognitive-behavioral Therapy for OCD. Guilford, New York 2004.

45. National Institute for Clinical Exellence. Core interventions in the treatment of obsessive-compulsive disorder and body dysmorphic disorder. Clinical guidelines 31. NICE, London 2005.

46. Simpson, HB, Liebowitz MR, Foa EB, et al. Post-treatment effects of exposure therapy and clomipramine in obsessive compulsive disorder. Depress Anxiety 2004; 19: 225-33.

47. Foa EB, Kozak MJ. Psycholocial treatments for obsessivecompulsive disorder. In: Mavissakalian MR, Prien RF, ed. Long-term Treatments of Anxiety Disorders. American Psychiatric Press, Washington DC 1996: 285-309.

48. Foa EB, Franklin ME, Moser J. Context in the clinic: How well do cognitive-behavioral therapies and medications work in combination? Biol Psychiatry 2002; 52: 987-97.

49. Foa EB, Liebowitz MR, Kozak MJ, et al. Randomized, placebo-controlled trial of exposure and ritual prevention, clomipramine, and their combination in the treatment of obsessive-compulsive disorder. Am J Psychiatry 2005; 162: 151-61

50. Franklin ME. Meeting in the middle, then moving forward together. In Abramowitz JS, Houts AC, ed. Concepts and Controversies in Obsessive Compulsive Disorder. Springer, New York 2005: 395-400.

51. Gould RA, Buckminster S, Pollack MH, Otto MW, Yap L. Cognitive-behavioral and pharmacological treatment for social phobia: A meta-analysis. Clin Psychol: Sci Pract 1997; 4: 291-306.

52. Clark DM, Ehlers A, McManus F, et al. Cogntive therapy versus fluoxetine in generalized social phoba: A randomized placebo-controlled trial. J Consult Clin Psychol 2003; 71: 1058-67.
53. Magee L, Erwin B, Heimberg R. Psychological treatment of social anxiety disorder and specific phobia. In: Antony MM, Stein MB, ed. Oxford Handbook of Anxiety and Related Disorders. Oxford University Press, New York 2009: 334-50.

54. Davidson JRT, Foa EB, Hubbert JD, et al. Fluoxetin comprehensive cognitive behavioral therapy, and placebo in generalized social phobia. Arch Gen Psychiatry 2004; 61 1005-13.

55. Antony MM, Barlow DH. Specific phobia. In: Barlow DH ed. Anxiety and Its Disorders. 2nd ed. Guilford, New York 2002: 380-418

56. Van Ameringen M, Mancini C, Patterson B. Pharmacotherapy for social anxiety and specific phobia. In: Antony MM, Stein MJ, ed. Oxford Handbook of Anxiety and Related Disorders. Oxford University Press, New York 2009: 321-34.

57. Wolitzky-Taylor KB, Horowitz JD, Powers MB, Telch MJ Psychological approaches in the treatment of specific phobias: A meta analysis. Clin Psychol Rev 2008; 28: 102137.

58. Brown TA, Campell LA, Lehman CL, Grisham JR, Mancill RB. Current and lifetime comorbidity of the DSM-IV anxiety and mood disorders in a large clinical sample. J Abnorm Psychol 2001; 110: 585-99.

59. Fava M, Rush AJ, Alpert JE, et.al. Difference in treatment outcome in outpaitents with anxious versus nonanxious depression: A STAR*D Report. Am J Psychiatry 2008; 165: 342-51.

60. McEvoy PM, Nathan P. Effectiveness of cognitive behavior therapy for diagnostically heterogeneous groups: a benchmarking study. J Consult Clin Psychol. 2007; 75: 34450.

61. Morrison N. Group cognitive therapy: treatment of choice or sub-optimal option? Behav Cogn Psychother 2001; 29: 311-32. 